Article

\title{
Cultural Sustainability in Ethnobotanical Research with Students Up to K-12
}

\author{
Lorena Gutiérrez-García $\left.{ }^{1} \mathbb{(}\right)$ José Blanco-Salas ${ }^{1, * \mathbb{C}}$, Jesús Sánchez-Martín ${ }^{2} \mathbb{D}$ and \\ Trinidad Ruiz-Téllez ${ }^{1}$ (D) \\ 1 Department of Plant Biology, Ecology and Earth Sciences, University of Extremadura, 06006 Badajoz, Spain; \\ lorenagg@unex.es (L.G.-G.); truiz@unex.es (T.R.-T.) \\ 2 Department of Science and Mathematics Education, Faculty of Education, University of Extremadura, \\ 06006 Badajoz, Spain; jsanmar@unex.es \\ * Correspondence: blanco_salas@unex.es; Tel.: +34-924-289-300
}

Received: 16 June 2020; Accepted: 10 July 2020; Published: 14 July 2020

\begin{abstract}
In the achievement of the Sustainable Development Goals (SDGs), education plays a fundamental role. However, traditional methodologies do not favor the enrichment and personal development essential to promote global awareness. The use of active methodologies based on experiences improve the quality of learning. This work describes the design, implementation, and evaluation of the acquired knowledge of a didactic proposal for non-formal education as a support for regulated education based on botany content. Firstly, a workshop was held, where young people participated directly in developing field work with a real scientific methodology. Subsequently, a group of students was chosen to be interviewed to obtain a global vision of the learning they obtained. The motivation of the students was quite positive, which allowed us to obtain voluntary participation in the field work and also gave the students a participative attitude throughout the development of the workshops. Four months later, this positive attitude remained during their direct involvement in various activities, and the students still remembered the fundamental content discussed. Relating the didactic proposal to its immediate environment was shown to increase interest in learning and value in its own context. The results of this educational experience have been very positive, as knowledge was acquired, and interest in the preservation of the environment and the profession of a researcher was promoted.
\end{abstract}

Keywords: active methodologies; Sustainable Development Goals; non-formal education; Ethnobotany; learning assessment; STEM

\section{Introduction}

Today, society demands new educational methodologies that encourage the active participation of the student, unlike traditional methods where the teacher is the protagonist [1]. Another modern issue is sustainability. This concept is an indisputable need that must be integrated into multiple fields, including teaching [2].

Since 1992, UNESCO (United Nations Educational, Scientific and Cultural Organization) has recognized and promoted education as a basic right for the promotion of sustainable development, but it is in the new World Agenda for Sustainable Development 2030 that this vision is made evident. In this document, education appears both as a specific goal and as a means to achieve all the Sustainable Development Goals (SDGs) [3]. Despite its relevance, SDGs are still unknown by a large majority of the society; some examples of this have been recently published [4].

SDGs constitute not only a traditional agenda of "things-to-do", but a fully comprehensive plan for reaching a specific level and way of development, at global scale [5]. Due to that, it is not possible to 
achieve one of them and not another; the entire program must be pursued as a common and complex target [6].

Education is the basis for promoting development, but it is also essential for personal enrichment, endowing individuals with skills and values and enabling them to be more versatile, critical, and resolute. In other words, developmental education facilitates an understanding between globalization and development by helping promote awareness of "global citizenship" [7]. The success of education would entail improvements in employment and reduce depopulation-problems that mainly affect rural areas. It has no sense focusing only on cognitive aspects of education, as the education process itself has revealed to be an integral path of developing many other competences, skills and variables $[8,9]$.

Here, the terms "education" and "sustainable rural development" intersect. Rural development refers to the need to establish a business fabric to make a territory strong and avoid problems such as population loss, emigration, aging, and poor economic diversity.

Initiatives are needed to adapt to the needs and constant changes that occur in society, thereby responding to the aforementioned problems, improving the standard of living of the inhabitants of rural areas, and helping to exploit and develop their sustainable environment [10].

The sociocultural context surrounding an individual is, in itself, a didactic technique that directly influences the learning process [11]. Students learn more effectively when using active methods and content similar to their daily lives and interests. Therefore, including traditional knowledge as an object of learning [12] can contribute to the perceived value of one's "own culture", which in turn is important for sustainable development, allowing people to harness their wealth to build their future, transforming it into processes of solidarity and popular economy [13].

Although many previous experiences already show the positive impact of non-formal education $[14,15]$, there are few references that focus on an inclusive way to promote so-called integral sustainability [5] - that is, an integrative vision of sustainability beyond environmental and ecological aspects. Thus, the current work presents a didactic experience that is primarily related to three of the SDGs and some of their goals:

- 4. Ensuring inclusive, equitable, and quality education and promoting lifelong learning opportunities for all (Quality Education), in the sense that it is necessary to ensure that all students acquire the knowledge required to achieve sustainable development;

- 12. Ensure sustainable consumption and production modalities (responsible production and consumption) due to the need for the efficient use of natural resources and waste reduction in order to achieve a more harmonious existence alongside the environment;

- 15. Sustainably manage forests, combat desertification, stop and reverse land degradation, and halt biodiversity loss (life of terrestrial ecosystems) to conserve our forests and biodiversity [16].

The scientific education of the population is essential for the transition to sustainability. Only in this way can we gain an understanding of the seriousness of the problems facing our planet and our way of life, as well as train future scientists capable of developing more efficient resources and to become citizens committed to achieving a sustainable society [17].

However, to accomplish the abovementioned goal, changes must be made in the traditional education system, moving from the present transmissionist tendency towards a more constructivist teaching pedagogy [18]. Teaching methodologies with the teacher at the center are still used in many disciplines, especially science. However, there is already evidence that the use of experience-based methodologies improves the quality of learning [19]. These principles are the basis of new science education approaches, such as the systematic integration of different science-related subjects in an entire knowledge construct as STEM or even including arts in STEAM.

Although human beings are born with the instinct to observe, discover and create, as we become adults, that desire to investigate becomes disconnected. Many young people have the preconceived idea that science is boring, difficult, and does not ensure a well-paid job in the future [20]. Among the 
main causes for a negative assessment of science is the organization of the educational system itself, as well as the poor relationship between the subject of study and daily lives of students [21,22].

As early as the 1980s, the need to develop the "scientific and technological literacy" of society was promoted to ensure that all citizens are able to make decisions on social issues in a democratic and responsible way [23]. Although actions have been taken since then, there is still a disconnect between what is planned and what is taught in the classroom. There is also a tendency to continue using traditional teaching methods [24]. An academic transformation at different educational levels is still needed, requiring new and more active and realistic teaching programs and methodologies.

Disinterest in science also affects the field of botany, showing a downward trend in botanical vocations in university. However, vegetables are an available and attractive teaching resource to promote a positive view of the sciences. This task is in the hands of educators. For students to develop an interest in science, the teacher must play a key role from an early age. To carry out this task, training in science is essential [25]. Sometimes, the scientific training received by teachers is limited, which represents an obstacle in the teaching of the natural sciences [26]. Direct collaboration between teachers and researchers is essential for the teacher's own training, as well as for the development of an integrated scientific curriculum [27].

The current article is focused on analyzing an educative experience that will be described below, with the following objective: To analyze the impact of a non-formal education activity on knowledge acquisition according to the framework for teaching Sustainable Development Goals (SDGs) conforming with an integral sustainability vision framework, as proposed by Zamora-Polo and Sánchez-Martín [5].

This general objective can be split into several research questions:

Question 1: Does a non-formal activity inserted into a standard academic space (a high school) have a positive impact on the knowledge acquisition of botanical and ethnobotanical concepts?

Question 2: Can a non-formal activity, if designed according to an integral sustainability vision framework, develop positive attitudes towards traditional knowledge preservation?

Question 3: Can a non-formal activity, if designed with close collaboration between secondary teachers and university researchers, promote the core concepts of the nature of science, such as what science is for and what kind of person a scientist is?

This research is structured in two phases. The first is the design and implementation of a didactic proposal that aimed to raise awareness among young people about the importance of preserving their ethnobotanical heritage and valuing it as a resource for sustainable development by involving the students in a realistic scientific study. The second phase examines, through interviews, the impact of this proposal on the achievement of the goals after a period of four months.

Consequently, this piece of research connects two traditional ways of scientific work: quantitative (stage 1) and qualitative (stage 2). This is made under the perspective of transversal research, which is quite common in ethnobotanical and athropological research [28].

\section{Materials and Methods}

\subsection{Relevance of the Location}

This work is part of a larger piece of research focused on the town of Hornachos, located in the autonomous community of Extremadura (Spain), adjacent to the protected area "Sierra Grande de Hornachos" included in the Natura 2000 Network [29].

The environmental richness of Hornachos is important [29] but is not the only reason we chose the area for this work. This environment brings together several features that make it especially interesting. On the one hand, it has great cultural richness resulting from its historical past featuring various cultures, such as Roman, Jewish, Arab, and Moorish. On the other hand, it has a great diversity of plants associated with traditional knowledge and uses [30].

However, this rich heritage is being lost due to the increase in intensive agriculture and globalization, leading to the abandonment of natural resources [31,32]. 
Many authors have already noted the importance of education as part of a developmental process to promote integral sustainability [33]. It is a challenge to include the conservation of rural areas and their ethnobotanical identities (understood as cultural and social heritage) in an educative proposal. This process requires the development of skills and experiences that enable the construction of learning based on an assessment [34].

\subsection{The Educative Center: Institute of Secondary Education (I.E.S), "Los Moriscos"}

The I.E.S., Los Moriscos, is located in the village of Hornachos, in the province of Badajoz (Extremadura) (Figure 1). This area was selected for its particular features, as Hornachos sits on the boundaries of the protected area of "Sierra Grande de Hornachos", which has several protection catalogs both regionally (Regional Zone of Interest (RZI)) and internationally (the Site of Community Importance (SIC), Special Protection Area for Birds (SPA), and Special Area of Conservation (SAC)), which are included in the Biodiversity Conservation Network of the European Union [35]. This area stands out for its cultivated varieties of wild plants with a rich historical-cultural legacy [36].

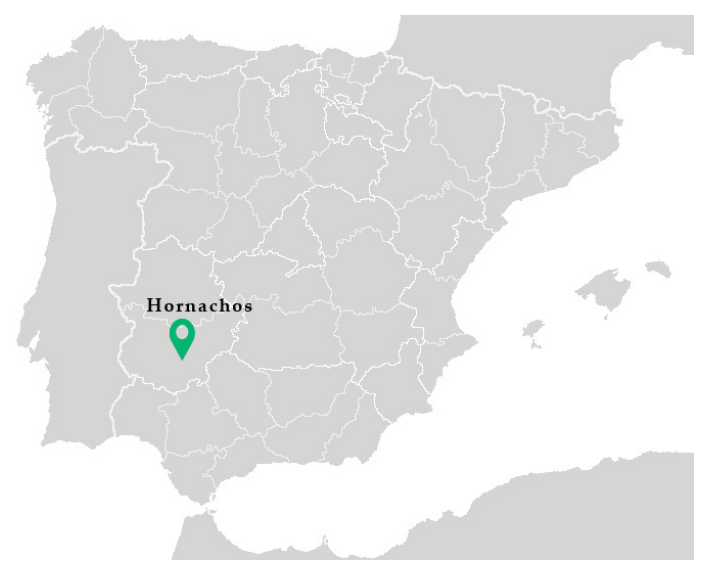

Figure 1. Location of the town of Hornachos in Extremadura, Spain. Source: Own elaboration.

It should be noted that the school in this area is a publicly owned rural secondary education institute created in 1997 and attended by students from various localities adjoining the protected area of "Sierra Grande de Hornachos", but the largest percentage is composed of young people from the town of Hornachos.

According to the corresponding data for the academic year of 2018-2019, the period of the first part of this study corresponding to the teaching workshops, the Center consisted of 368 students distributed at the Secondary Education levels, including those in a baccalaureate in the modalities of sciences, technology, humanities, and social sciences as well as those in the formative cycle of the middle degree, "Attention to people in situations of dependence". In addition, the Center had a staff of 48 teachers and 9 members of non-teaching staff working as computer scientists, administrators, concierges, social educators, etc.

This Center has a "low" socioeconomic level [37], and most of the students' families live off agriculture, livestock, or construction. In addition, the immigrant rate is low, and no significant differences were found in either socioeconomic conditions or cultural and religious ones.

\subsection{Participating Students}

The entire design of the educative intervention was done on the basis of a tight collaboration with the teachers. Based on a prior agreement with the Center's teaching and management team, K-9 students were distributed into 4 groups, totaling 72 young people between the ages of 13 and 16 .

This level was chosen because of its near-adult cognitive development and proximity to the end of compulsory studies, as determined by the Spanish administrations [38]. Since it did not inconvenience 
the workshop objectives, the representation of students from locations other than Hornachos was not taken into account because of their small representation and also because this study was not interested in excluding certain students but in arousing interest in research, the value of one's own resources, and the promotion of sustainable development awareness in young people.

Following the ethics of data protection, identification of the interview participants is done using fictional names. In addition, all participants gave consent to be recorded and have their answers used as part of this academic research.

\subsection{The Educational Proposal}

A pedagogical proposal was made consisting of a workshop based on the scientific method and research applied to Ethnobotany called "Learning to research in our protected space-Sierra Grande de Hornachos". This proposal was part of the program "The Week of Science and Technology in Extremadura", an oriented program focused on K-8 to K-12 students from public or private centers, which has been held annually since 2017 and whose main objective is to promote scientific culture and its dissemination.

The didactic proposal was divided into 3 milestones, carried out over 3 days and lasting $2 \mathrm{~h}$ each, within school hours. The participation of the Center's director and faculty of teachers was necessary. Every day, the workshop was attended by all the selected students accompanied by a group of teachers (ranging from 3 to 4 teachers) who depend on shift work or whose schedules were dedicated to the workshop.

The content of the workshop focused on the significant interculturality that persists in knowledge linked to wild and cultivated plant species of enormous value [30].

The activities carried out are detailed below and summarized in Figure 2.

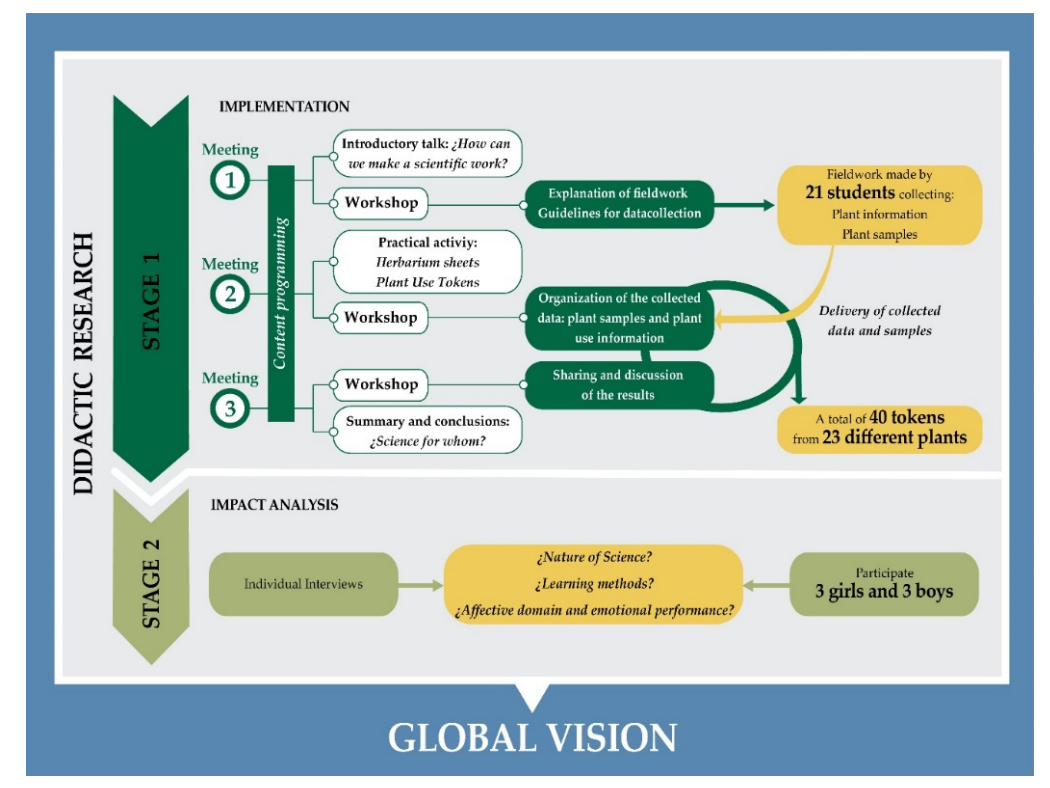

Figure 2. Graphic summary of the study process. Source: Own elaboration.

Milestone 1 (first session). Introductory talk on the work carried out by scientific staff, the importance of the promotion of science, and the scientific method, an exhibition of workshop objectives and programming, an explanation of fieldwork or practical workshops, and the delivery of data collection sheets and guidelines to follow.

Milestone 2 (second session). Collection of tokens and samples by students and resolving any doubts; practical activity: preparation of herbarium sheets with vegetable samples of Arbutus unedo L., a typical plant in the study area. 
Milestone 3 (third session). Sharing and discussion of the results obtained from the collection of data carried out by students, highlighting the most significant plant species, and discussion and conclusions of the sessions.

Below is the field activity or hands-on workshops conducted by students outside the classroom. These tasks consisted of each student choosing one or two adults over the age of 70 to be treated as an ethnobotanical informant. The selected persons could be family, but they had to be linked to rural life and should, therefore, know the traditional uses associated with wild or cultivated plant species. Students had to ask about the traditional uses that local wild or cultivated plants might have in this particular area.

A model table was used for data collection. Each student was given two tabs (Figures 3 and 4) that served as a script and included informed consent informing them about the research and the purpose of the collection of the data, which all the interviewed adults signed. Each of these tables was identified with a different tab code, making it easy to identify later.
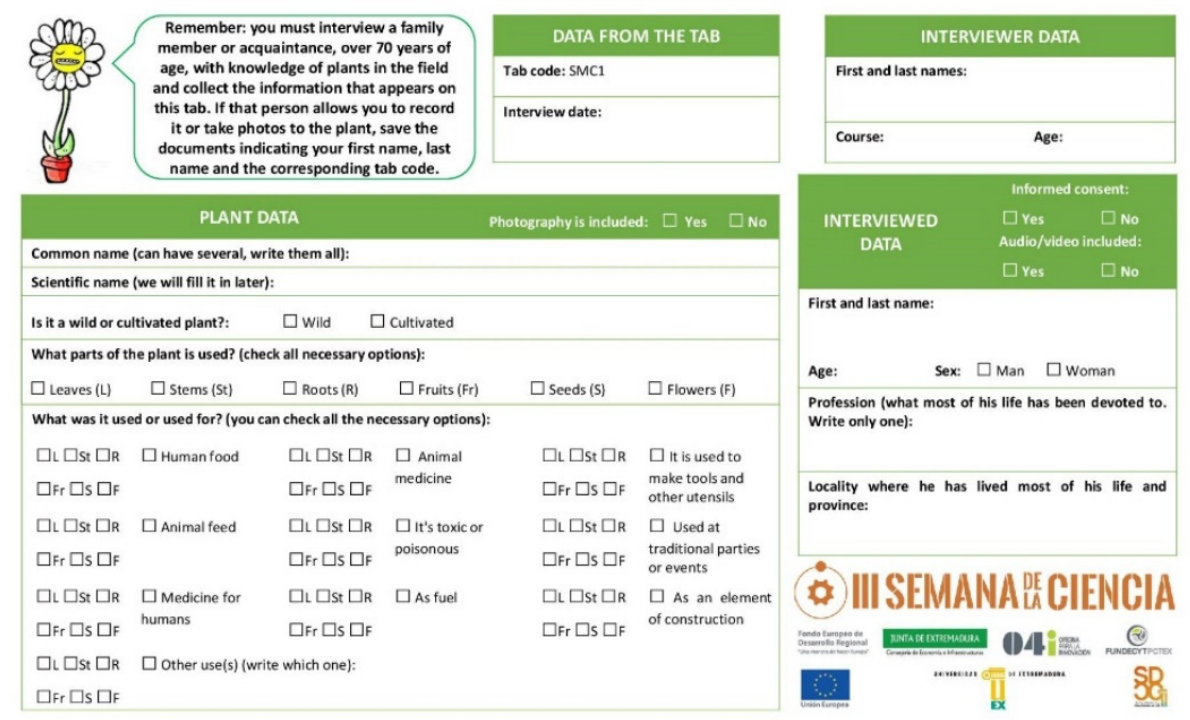

Figure 3. Data collection sheet provided to students (front).

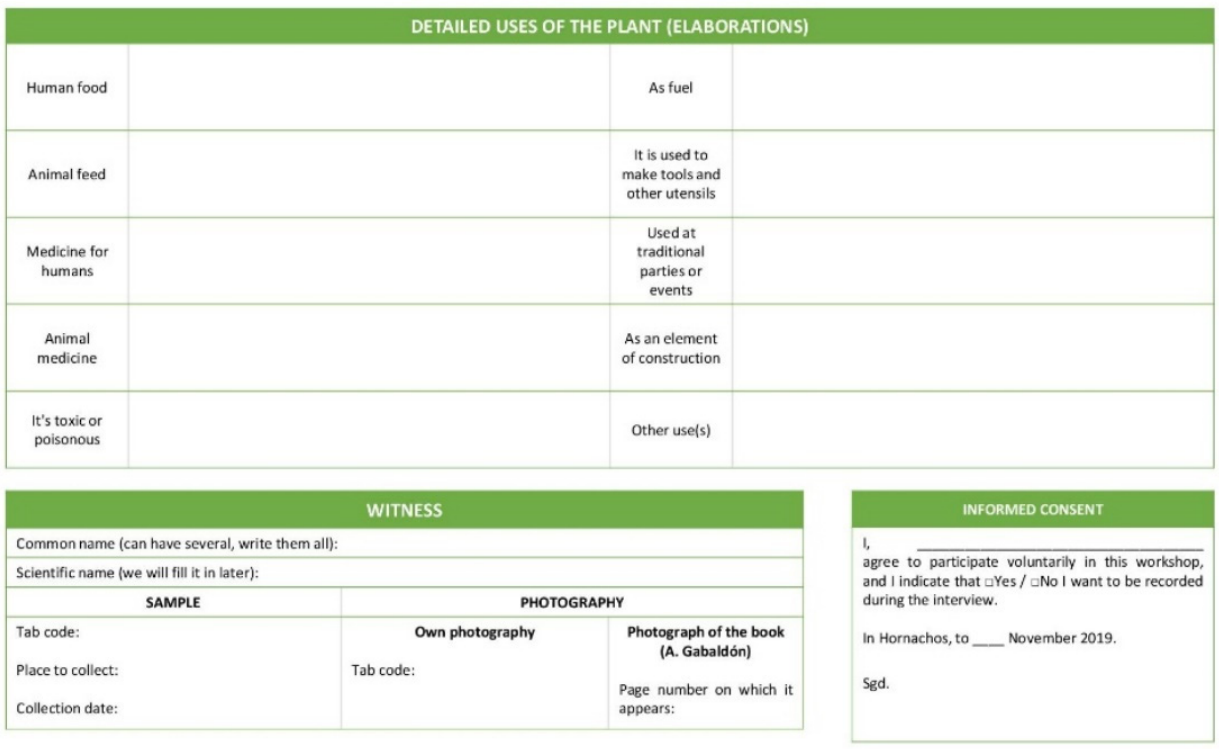

Figure 4. Data collection sheet provided to students (back). Source: Own elaboration. 
For the design of the data collection sheet, 10 subcategories of use were considered based on those described in the Spanish Inventory of Traditional Knowledge Relating to Biodiversity [39]. Each of these subcategories was quoted verbally during the workshops for each of the plants, while the interviewer (student) wrote the information given by the informants. The following subcategories relate to the types of uses that a plant can have for humans: 1. Human food; 2. Animal feed; 3. Medicine for humans; 4. Animal medicine; 5. Toxic or poisonous; 6. Fuel; 7. Used to make tools and other utensils; 8. Used for traditional parties or events; 9. Used as a building element; 10. Other uses.

The time spent on each interview was variable and depended on the work done by each student. The tokens, samples, and photographs provided were collected by the researchers during the second day of the workshop, and the data were digitized at the Botany Laboratory of the University of Extremadura to be exhibited and, in the last session, debated in the classroom.

\subsection{Data Analysis}

Both quantitative and qualitative mixed methodologies were considered [40]. In the analysis of the development of the workshop as well as the practical workshops carried out by the students, the quantitative logic was applied, while in the second part of this research, open interviews were conducted with a small group of student participants in the workshop whose results were qualitatively analyzed to assess the educational impact of the proposed activity. In this last case, the individuals were selected according to what the teachers suggested when they were asked for students that could comply the following conditions: (a) They attended the activity; (b) they were not especially brilliant students or had a clear and evident motivation towards the sciences; and (c) they came from the village and had the opportunity to connect with their own relatives in ethnobotanical research.

For the second part of this work, direct, unstructured interviews were used to avoid limiting the interviewee's responses [41].

Six students, 3 boys and 3 girls, were selected. All students had participated in the face-to-face workshop and also showed interest and involvement in the practical workshops, delivering truthful information on two plant species collected in the tokens provided to them along with a sample and/or a photograph of those plants as a sample.

The interviews were conducted individually in the month of March 2020 during school hours in the time dedicated to recess. This period was four months after the activity itself took place, so the responses and the whole conversation can be considered a memory of the practical workshop.

To facilitate comfort and conversation, 6 open-type issues were designed for obtaining information on the impact of the conferences held in the first phase and for determining their educational impact. These issues were the initial starting point for a fruitful conversation that was recorded and analyzed. Three fields of study or variables were thus established: 1 . Learning about science, 2 . Learning about botany, and 3. Emotional performance. Thus, the number of issues for each variable is 3 . Over the course of the interviews, the interviewer used the pre-designed questions as a guide and was able to pose them in a different order or ask other secondary questions (but always keeping in mind the objectives).

The data were collected by using audio recordings and field notebook annotations. Two different experts analyzed each recording to identify the particular expressions for each variable. Afterwards, a third expert contrasted both codifications and made them reach a consensus for qualified data codification.

\section{Results and Discussion}

\subsection{Quantitative Data Analysis: The Workshop}

Curiosity and motivation are essential for learning. This is determined not only by the teacher's performance or the subject matter but also by the teaching methodologies employed [42]. Traditionally, methodologies have been promoted where the teacher is the protagonist and the student is a simple 
recipient; however, more active methodologies involve the participation and direct intervention of the student in concrete or everyday experiences, which allows greater activation of knowledge [43,44].

During the development of the present workshop, the direct involvement of the students in the practical activities was varied. On the first and third days, where the methodology used involved speaking or discourse, the performance of the students was more passive, showing an increase in interest when the analysis and discussion of the results obtained from the fieldwork was carried out, suggesting that this work was a topic of interest to the students; in the second part, all the students became involved, although this was not an optional decision.

Moreover, in the workshop that took place outside the classroom, motivation was an important factor. Several authors argue that the choice of the subject of study is essential to achieve greater learning [45]. Further, not all students attending the workshop participated in the practical workshops held outside the classroom because such workshops were not mandatory. More than $29 \%$ (nearly a third) of students conducted interviews with their elders and collected the information in the pieces previously provided to them. Thus, a total of 21 students collected a total of 40 tokens and, therefore, almost all students collected information from two plants. Specifically, 19 of them collected information from 2 plant species, among which 4 students also delivered plant photographs and samples, and 2 students contributed a sheet with 1 species per person, one of which was accompanied by a photograph and vegetable sample.

Information was collected from 23 different plants-9 cultivated (Aloe vera (L.) Burm. F., Citrus $x$ sinensis (L.) Osbeck, Ficus carica L., Gossypium sp., Olea europaea subsp europaea var. sylvestris (Mill.) Lehr., Punica granatum L., Rosmarinus officinalis L., Solanum lycopersicum L., and Ziziphus jujuba Mill.), and 14 wild plants (Arbutus unedo L., Cistus ladanifer L., Crataegus monogyna Jacq., Cyperus sp., Daphne gnidium L., Erica sp., Eucalyptus camaldulensis Dehnh., Heliotropium europaeum L., Hypericum perforatum L., Quercus rotundifolia Lam., Retama sphaerocarpa (L.) Boiss., Rumex pulcher L., Thymus sp., and Urtica urens L.), some of which appeared more frequently than others (Figure 5). Among the most represented were Arbutus unedo and Thymus sp., indicating that these species are of great interest to the ethnobotanical identity of Sierra Grande.

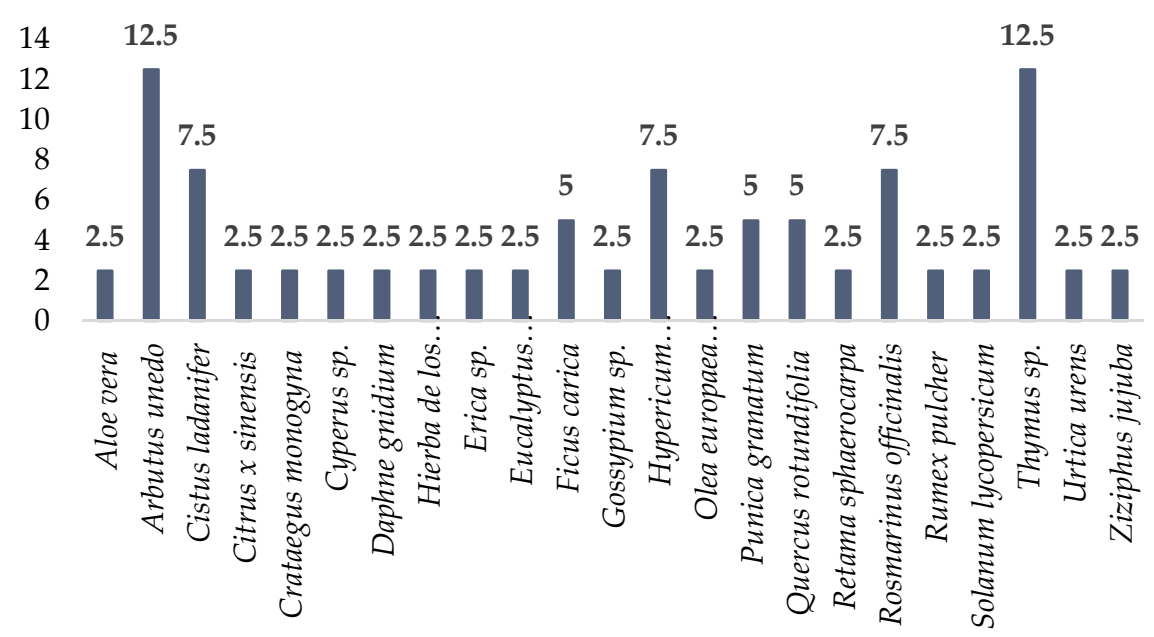

Figure 5. Frequency with which each species appeared in the collected tokens.

A total of 80 uses were obtained, the majority of which were, in order of majority of use: 2. Animal feed, 3. Medicine for humans, and 1. Human food (Figure 6). The maximum number of uses obtained for the same species was 8, and this figure was only achieved for Arbutus unedo, followed by Thymus sp. with 7 and Crataegus monogyna with 6 . From the set of extracted information, we also observed that the most commonly used parts of the plant were the Leaves (L) and Stems (St), which were consumed from more than 13 of the 23 total plants. Least used were the Seeds (S), which were only used for three 
species (Ficus carica, Retama sphaerocarpa, and Urtica urens). Flowers (F) and Fruits (Fr) were also used for more than $40 \%$ of species (Appendix A).

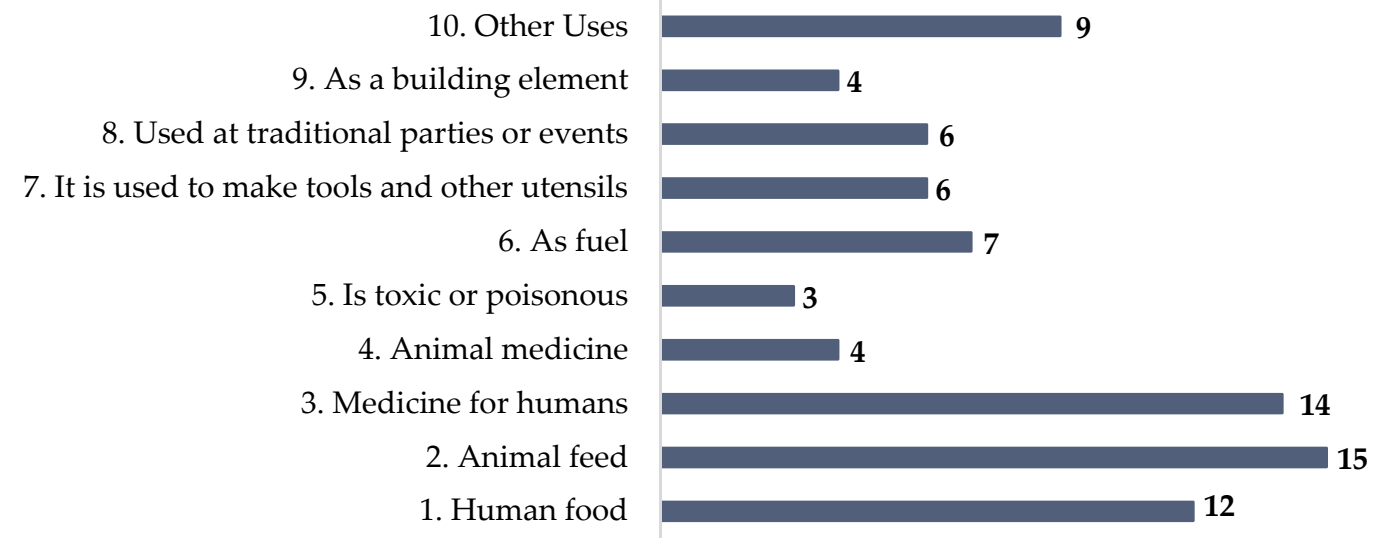

Figure 6. Total uses obtained by subcategory.

The Autonomous Community of Extremadura is one of the Spanish regions with the fewest ethnobotanical studies [46]. Most studies focus on medicinal and veterinary plants [47-57]. However, few enclaves in the region have had in-depth studies on the traditional knowledge that communities possess about their plants. Two exceptions are the Monfragüe National Park, in the province of Cáceres [58], and Calabria and Siberia in Badajoz province [59]. For the Regional Zone of Interest (RZI), Sierra Grande de Hornachos, only one recent study has been done on edible plants [60]. Therefore, the results obtained by the students, which may seem modest, have high scientific interest since most of the uses collected are novel for the area and, in some cases, are novel for the region.

The results reveal that the students who participated did so with total involvement. In general, the group proved to be curious and interested in the plants and cultural richness of their environment, which is a very interesting source of knowledge.

\subsection{Qualitative Data Analysis: The Interviews}

Analysis of the six interviews offered interesting insights into the three study fields: nature of science, learning methods, and affective domain and emotional performance. Since a qualitative methodology was used, the most relevant results were obtained by examining samples from the recorded interviews. The entire text for these interviews is available upon request. The following section offers samples from the interviews.

\subsubsection{About Nature of Science (NOS)}

These interviews included several specific questions on how the students understand some of the core concepts of the nature of science, such as: "What do you think science is? What is science for? What do you know about the Scientific Method?" and "What is a scientist for you?" Students had difficulties defining these concepts, which agrees with previous studies [61], but some understandings were clear:

"Science is important for society." (Individual 1)

"Science is knowledge, and there are many kinds of scientists." (Individual 3)

"Science explains reality." (Individual 3)

These students presented epistemologic statements about the focus of science and how it influences their lives. Furthermore, when asked about scientists and the scientific method, they said:

"Science method is a pathway, a procedure for researching." (Individual 2) 
"A scientist has to have interest in details and be rigorous, careful ... Science cannot be made with fuzzy borders." (Individual 3)

"A scientist cannot be subjective, but objective." (Individual 4)

The interviewees easily identified some of the most relevant values of science in itself [62], such as objectivity, reliability, methods, and systematicity.

\subsubsection{About the Botanical Learning Method}

An important insight of the current work is to determine how important the method is that we use to teach science, particularly botanical science. In this sense, the students again expressed ideas that were different from traditional ways of learning:

"I like plants. What I liked the most was the practical activity with the strawberry tree." (Individual 2) "[Making things directly by hand] is a very motivating way of learning. I felt ready to make new things and to learn." (Individual 3)

"Question: Is it easier to learn in this way? Answer: Yes, yes, much better. This is better than writing all the time." (Individual 5)

"The most boring part was the initial oral exposition." (Individual 6)

\subsubsection{About Sustainability as An Integral Concept Involving Ethnobotanical Ideas}

Cultural sustainability is not a very frequently taught subject when discussing sustainability concepts. Indeed, the relevance of cultural sustainability was only recently framed [5]; presently, it is not possible to talk about sustainability without mentioning cultural sustainability. In this sense, the interviews exhibited the acquisition of several interesting ideas:

"Question: Do you think it is important to preserve these uses for these plants (traditional medicine usages)? Answer: Yes, so in the future we will be able to know how the past was." (Individual 1)

"I have learned some new information about plants and how to keep in contact with nature." (Individual 4)

"I have learned general culture about the plants that are around us in our town. We should be proud of living in such a beautiful place, with a lot of plants with interesting usages. This is part of our town and its history." (Individual 5)

\subsubsection{Feelings, Self-Regulation, and Emotional Performance of the Learning Process}

Lastly, the core dimensions of education, such as self-regulation of the learning process, and several emotional aspects emerged during the interviews, as can be seen in the following statements:

"The practical workshop helped me learn more vegetal species. I already knew some of them, but now I can identify more." (Individual 1)

"I felt happy; nothing made me feel bored." (Individual 2)

"I would recommend using these kinds of activities again during the course." (Individual 6)

Qualitative analysis of the interviews revealed effectiveness in the acquisition of many types of knowledge, not only knowledge related to botanical learning but also the understanding of ethnobotanical issues, the value of cultural sustainability, and even an understanding of various aspects related to the nature of science. In addition, since these interviews were carried out several months after the activity, they revealed a significant recall of related knowledge.

\section{Conclusions and Further Studies}

Considering the results obtained, we conclude that the use of training techniques and tools based on active methodologies provides an interesting resource to generate knowledge in symbiosis 
with traditional classroom teaching (i.e., for Ethnobotany in the "Sierra Grande" protected area of Hornachos).

This piece of research has revealed the significant and strong relationship between apparently disconnected disciplines such as ethnobotanical and science education. Further studies should be oriented in similar directions and can be guided by research questions such as "What relationship appears between talking about traditional knowledge and science education? Is it possible to raise the interest in science if we focus on scientific knowledge from our ancestors?" Hornachos and its environment, its richness and its potential natural resources surely could address these and other similar intuitions.

This work has shown that a non-formal activity inserted into a standard academic space (a high school) has a positive impact on the acquisition of botanical and ethnobotanical knowledge. Moreover, if designed according to an integral sustainability vision framework, students can develop positive attitudes towards traditional knowledge preservation. Further, if designed with close collaboration between secondary teachers and university researchers, this type of activity can promote the core concepts of the nature of science, such as what science is for, and what kind of person a scientist is.

Author Contributions: Conceptualization and methodology, J.S.-M.; software, L.G.-G.; validation, J.B.-S.; formal analysis L.G.-G.; investigation, J.B.-S. and L.G.-G.; resources, T.R.-T.; data curation, L.G.-G.; writing—original draft preparation, L.G.-G. and T.R.-T.; writing-review and editing, J.B.-S.; visualization, L.G.-G.; supervision, J.S.-M.; project administration, J.B.-S.; funding acquisition, T.R.-T. All authors have read and agreed to the published version of the manuscript.

Funding: This research was funded by the Junta de Extremadura (Spain) and the European Regional Development Fund through grant number IB16003.

Acknowledgments: The authors would like to extend their sincere thanks to the town of Hornachos and the collaboration of the I.E.S. of "Los Moriscos" for their cooperation during the fieldwork.

Conflicts of Interest: The authors declare no conflict of interest. 


\section{Appendix A}

Table A1. Data obtained by students in the workshops. Uses given to each plant during the workshops appear in green.

\begin{tabular}{|c|c|c|c|c|c|c|c|c|c|c|c|c|c|c|}
\hline 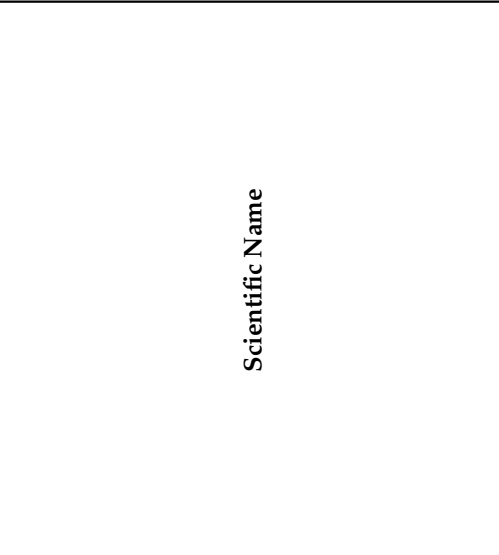 & 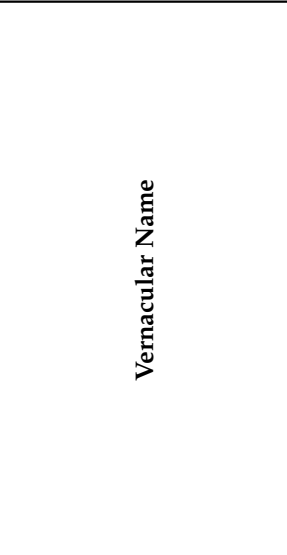 & 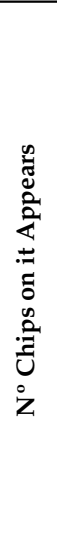 & 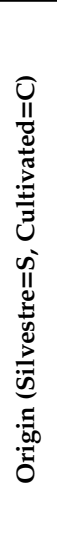 & 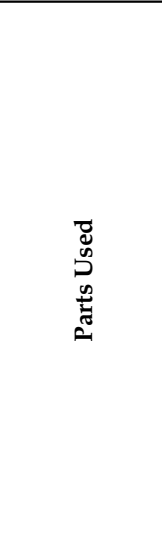 & 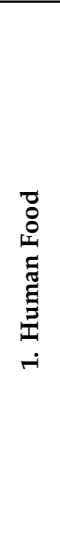 & 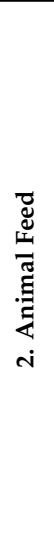 & 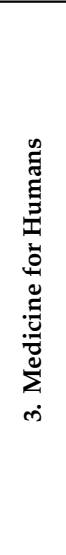 & 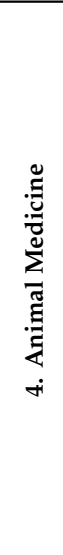 & 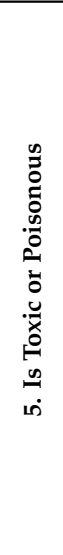 & 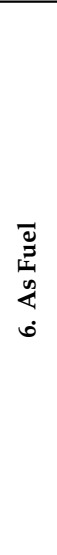 & 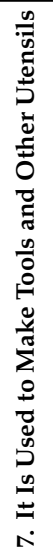 & 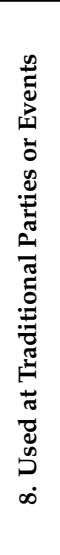 & 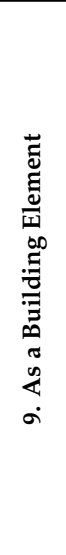 & 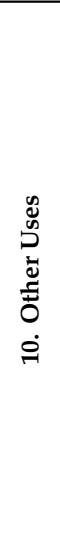 \\
\hline Aloe vera & Aloe vera & 1 & $\mathrm{C}$ & $\mathrm{L}$ & & & & & & & & & & \\
\hline Arbutus unedo & Madroño, madroñera & 5 & $\mathrm{~s}$ & $\mathrm{~L}, \mathrm{St}, \mathrm{R}, \mathrm{Fr}, \mathrm{F}$ & & & & & & & & & & \\
\hline Cistus ladanifer & Jara & 3 & $\mathrm{~s}$ & L, St, R, F & & & & & & & & & & \\
\hline Citrus $x$ sinensis & Naranjo & 1 & $\mathrm{C}$ & $\mathrm{L}, \mathrm{St}, \mathrm{Fr}$ & & & & & & & & & & \\
\hline Crataegus monogyna & Tilero & 1 & $\mathrm{~s}$ & $\mathrm{St}, \mathrm{Fr}, \mathrm{F}$ & & & & & & & & & & \\
\hline Cyperus sp. & Juncia & 1 & $\mathrm{~s}$ & $\mathrm{~L}, \mathrm{St}$ & & & & & & & & & & \\
\hline Daphne gnidium & Torvisca & 1 & $\mathrm{~s}$ & St & & & & & & & & & & \\
\hline Heliotropium europaeum & Hierba de los alacranes & 1 & $\mathrm{~s}$ & $\mathrm{~F}$ & & & & & & & & & & \\
\hline Erica sp. & Brezo & 1 & $\mathrm{~s}$ & $\mathrm{~F}$ & & & & & & & & & & \\
\hline Eucalyptus camaldulensis & Eucalipto & 1 & $\mathrm{~s}$ & $\mathrm{~L}$ & & & & & & & & & & \\
\hline Ficus carica & Higuera & 2 & $\mathrm{C}$ & $\mathrm{Fr}, \mathrm{S}, \mathrm{F}$ & & & & & & & & & & \\
\hline Gossypium sp. & Planta de algodón & 1 & $\mathrm{C}$ & $\mathrm{Fr}$ & & & & & & & & & & \\
\hline Hypericum perforatum & Árnica & 3 & $\mathrm{~s}$ & $\mathrm{~L}, \mathrm{St}, \mathrm{F}$ & & & & & & & & & & \\
\hline Olea europaea subsp. europaea var. sylvestris & Olivo & 1 & C & $\mathrm{L}, \mathrm{Fr}$ & & & & & & & & & & \\
\hline Punica granatum & Granado & 2 & $\mathrm{C}$ & $\mathrm{L}, \mathrm{St}, \mathrm{R}, \mathrm{Fr}$ & & & & & & & & & & \\
\hline Quercus rotundifolia & Encina & 2 & $\mathrm{~s}$ & St, Fr & & & & & & & & & & \\
\hline Retama sphaerocarpa & Retama & 1 & $\mathrm{~s}$ & $\mathrm{~L}, \mathrm{St}, \mathrm{Fr}, \mathrm{S}, \mathrm{F}$ & & & & & & & & & & \\
\hline Rosmarinus officinalis & Romero & 3 & $\mathrm{C}$ & $\mathrm{L}, \mathrm{F}$ & & & & & & & & & & \\
\hline Rumex pulcher & Romaza & 1 & $\mathrm{~s}$ & $\mathrm{~L}, \mathrm{St}, \mathrm{R}$ & & & & & & & & & & \\
\hline Solanum lycopersicum & Tomatera & 1 & $\mathrm{C}$ & $\mathrm{Fr}$ & & & & & & & & & & \\
\hline Thymus sp. & Tomillo & 5 & $\mathrm{~s}$ & $\mathrm{~L}, \mathrm{St}, \mathrm{R}, \mathrm{F}$ & & & & & & & & & & \\
\hline Urtica urens & Ortiga & 1 & $\mathrm{~s}$ & L, S & & & & & & & & & & \\
\hline Ziziphus jujuba & Azufaifa & 1 & C & $\mathrm{L}, \mathrm{St}, \mathrm{Fr}$ & & & & & & & & & & \\
\hline
\end{tabular}




\section{References}

1. Miguel-Dávila, J.A.; López-Berzosa, D.; Martín-Sánchez, M. Una participación activa del alumno pronostica una buena nota en el examen? (Does the active participation of students serve as a predictor of good marks achievement?). WPOM Work. Pap. Oper. Manag. 2012, 3, 71-83. [CrossRef]

2. Hernández-Barco, M.; Sánchez-Martín, J.; Blanco-Salas, J.; Ruiz-Téllez, T. Teaching Down to Earth-Service-Learning Methodology for Science Education and Sustainability at the University Level: A Practical Approach. Sustainability 2020, 12, 542. [CrossRef]

3. Rieckmann, M. Educación para los Objetivos de Desarrollo Sostenible: Objetivos de Aprendizaje; Google Libros; UNESCO Publishing: Paris, France, 2017. ISBN 9789233000704.

4. Zamora-Polo, F.; Sánchez-Martín, J.; Corrales-Serrano, M.; Espejo-Antúnez, L. What Do University Students Know about Sustainable Development Goals? A Realistic Approach to the Reception of this UN Program Amongst the Youth Population. Sustainability 2019, 11, 3533. [CrossRef]

5. Zamora-Polo, F.; Sánchez-Martín, J. Teaching for a better world. Sustainability and Sustainable Development Goals in the construction of a change-maker university. Sustainability 2019, 11, 4224. [CrossRef]

6. González-Domínguez, J.; Sánchez-Barroso, G.; Zamora-Polo, F.; García-Sanz-Calcedo, J. Application of Circular Economy Techniques for Design and Development of Products through Collaborative Project-Based Learning for Industrial Engineer Teaching. Sustainability 2020, 12, 4368. [CrossRef]

7. Fondón-Ludeña, A.; Gómez-Quintero, J.D.; López-Ramos, V.M.; Neila-Boyer, I.; Remacha-Fernández, M.; Robayo-Zambrano, D. La Pertinencia de la Educación para el Desarrollo y la Ciudadanía Global en el Segundo Ciclo de Educación Infantil en Aragón y Extremadura; Asamblea de Cooperación por la Paz: Merida, Spain, 2014.

8. Zamora-Polo, F.; Martínez Sánchez-Cortés, M.; Reyes-Rodríguez, A.M.; García Sanz-Calcedo, J. Developing Project Managers' Transversal Competences Using Building Information Modeling. Appl. Sci. 2019, 9, 4006. [CrossRef]

9. Sánchez-Barroso, G.; González-Domínguez, J.; García-Sanz-Calcedo, J.; Zamora-Polo, F. Analysis of Learning Motivation in Industrial Engineering Teaching in University of Extremadura (Spain). Sustainability 2020, 12, 4987. [CrossRef]

10. Álvarez Cáceres, B. Juventud y Emprendimiento en el Mundo Rural; Universidad de Valladolid: Valladolid, Spain, 2014.

11. Rosas Arellano, J. La importancia del contexto en el diseño de política social. Revista Digital para Profesionales de la Enseñanza 2009, 5, 1-7. [CrossRef]

12. Martínez Naharro, S.; Bonet Espinosa, P.; Cáceres González, P.; Fargueta Cerdá, F.; García Felix, E. Los objetos de aprendizaje como recurso de calidad para la docencia: Criterios de validación de objetos en la Universidad Politécnica de Valencia. CEUR Workshop Proc. 2007, 318, 1-12.

13. Bonfil, G. El Etnodesarrollo: Sus Premisas Jurídicas, Políticas y de Organización; Docip, Etnocidio y Etnodesarrollo: San José, Costa Rica, 1981.

14. Borreguero, G.M.; Correa, F.L.N.; Núñez, M.M.; Martín, J.S. Recreational experiences for teaching basic scientific concepts in primary education: The case of density and pressure. EURASIA J. Math. Sci. Technol. Educ. 2018, 14, em1616. [CrossRef]

15. Francl, M. Homemade chemists. Nat. Chem. 2012, 4, 687-688. [CrossRef] [PubMed]

16. Naciones Unidas. Objetivos de Desarrollo Sostenible. Available online: https://www.un.org/ sustainabledevelopment/es/objetivos-de-desarrollo-sostenible/ (accessed on 2 March 2020).

17. Vilches, A.; Pérez, D.; Calero, M. Contribución de la educación científica a la apropiación de los objetivos de desarrollo sostenible. In Proceedings of the IX Congreso Internacional Sobre Investigación en Didáctica De Las Ciencias, Girona, Spain, 9-12 September 2013.

18. Álvarez Salgado, E.; Arias Guevara, H. El Aprendizaje De Algunos Conceptos Fundamentales En El Campo De La Botánica. Una Experiencia Investigación Aula. TED Tecné Episteme y Didaxis 2017, 69-73.

19. Hanh, N.T.K. Applying Some Modern Methods and Techniques in Teaching Chemistry to Develop Students' Competence in Vietnam. World J. Chem. Educ. 2018, 6, 184-189.

20. Rodríguez, J.M.M.; Serrano, M.J.H.; González, S.S.; Rodríguez, J.M.M.; Serrano, M.J.H.; González, S.S. El interés por el conocimiento científico de los estudiantes de Secundaria en España. Educação Sociedade 2019, 40. [CrossRef] 
21. Solbes, J.; Montserrat, R.; Furió Más, C. Desinterés del alumnado hacia el aprendizaje de la ciencia: Implicaciones en su enseñanza. Didáctica Las Ciencias Experimentales Y Sociales 2007, 117, 91-117.

22. Solbes, J.; Vilches, A. Investigación didáctica: Papel de las relaciones entre ciencia, tecnología, sociedad y ambiente en la formación ciudadana. Enseñanza Las Ciencias 2004, 22, 337-348.

23. Acevedo Díaz, J. Ciencia, Tecnología y Sociedad (CTS): Un enfoque innovador para la enseñanza de las ciencias. Revista Educación La Universidad Granada 1997, 10, 269-275.

24. Martín-Gordillo, M.; Tedesco, J.C.; López-Cerezo, J.A.; Acevedo-Díaz, J.A.; Echevarría, J.; Osorio, C. Educación, Ciencia, Tecnología Y Sociedad; Centro de Altos Estudios Universitarios de la OEI, Ed.; Centro de Altos Estudios Universitarios: Madrid, Spain, 2000. ISBN 9788476662151.

25. García-Berlanga, O. Las plantas como recursos didáctico. La Botánica en la enseñanza de las Ciencias. Flora Montiberica 2019, 73, 93-99.

26. Chakour, R.; Alami, A.; Selmaoui, S.; Eddif, A.; Zaki, M.; Boughanmi, Y. Earth Sciences Teaching Difficulties in Secondary School: A Teacher's Point of View. Educ. Sci. 2019, 9, 243. [CrossRef]

27. Riquarts, K.; Hansen, K.-H.H.; Una, P.; Del, D. Collaboration among teachers, researchers and in-service trainers to develop an integrated science curriculum. J. Curric. Stud. 1998, 30, 661-676. [CrossRef]

28. Kottak, C.P. Cultural Anthropology, 15th ed.; McGraw-Hill Education: New York, NY, USA, 2013.

29. Natura 2000 Standard Dataform. Sierra Grande de Hornachos. 2000. Available online: http://natura2000.eea. europa.eu/Natura2000/SDF.aspx?site=ES0000072 (accessed on 20 February 2020).

30. Blanco-Salas, J.; Gutiérrez-García, L.; Labrador-Moreno, J.; Ruiz-Téllez, T. Wild Plants Potentially Used in Human Food in the Protected Area Sierra Grande de Hornachos of Extremadura (Spain). Sustainability 2019, 11, 456. [CrossRef]

31. Carvalho, A.M.; Barata, A.M. The consumption of wild edible plants. In Wild Plants, Mushrooms and Nuts; Wiley: Hoboken, NJ, USA, 2016; pp. 169-198.

32. Jug-Dujaković, M.; Łukasz, Ł. The contribution of Josip Bakić's research to the study of wild edible plants of the adriatic coast: A military project with ethnobiological and anthropological implications. Slovak Ethnol. 2016, 2, 158-168.

33. Lozano, R.; Lukman, R.; Lozano, F.J.; Huisingh, D.; Lambrechts, W. Declarations for sustainability in higher education: Becoming better leaders, through addressing the university system. J. Clean. Prod. 2013, 48, 10-19. [CrossRef]

34. Bastidas Mora, J.R.; Florez Onofre, M.A. Evaluación en el Aprendizaje de las Ciencias Naturales en los Estudiantes de Grado Quinto, de la Institución Educativa Municipal Ciudad de Pasto, Sede Lorenzo de Aldana; Universidad de Nariño: San Juan de Pasto, Colombia, 2014.

35. Junta de Extremadura. Áreas Protegidas de Extremadura. Available online: http://extremambiente.juntaex. es/index.php?option=com_content\&view =article\&id=1285\&Itemid=459 (accessed on 21 February 2020).

36. Contreras, J. ¿Seguimos siendo lo que comemos? In Identidad a Través de la Cultura Alimentaria; Comisión Nacional para el Conocimiento y Uso de la Biodiversidad: Mexico City, Mexico, 2013; p. 214, ISBN 978-607760-7779.

37. Instituto de Estadística de Extremadura Mapas Municipales. Atlas Socioeconómico de Extremadura; IEEX, Ed.; Junta de Extremadura: Mérida, Spain, 2019; p. 12.

38. Ley Orgánica 8/2013, de 9 de Diembre, Para la Mejora de la Calidad Educativa; Boletín Oficial del Estado: Madrid, Spain, 2013; p. 64.

39. Inventario Español de los Conocimientos Tradicionales Relativos a la Biodiversidad; MAPA (Ed.) 1a.; Ministerio de Agricultura: Madrid, Spain, 2019.

40. Creswell, J. Research Design Cressweell 2014; 4a; SAGE: Thousand Oaks, CA, USA, 2014.

41. Vargas Jiménez, I. La entrevista en la investigación cualitativa: Nuevas tendencias y retos. Revista Electrónica Calidad Educación Superior 2012, 3, 119-139.

42. Junco Herrera, I. La motivación en el proceso ensenanza-aprendizaje. Temas Educación 2010, 9, 1-14.

43. Canós, L.; Mauri, J. Metodologías Activas para la Docencia y Aplicación de las Nuevas Tecnologías: Una Experiencia; Universidad Politécnica de Valencia: Valencia, Spain, 2005.

44. Abellán Toledo, Y.; Herrada Valverde, R.I. Innovación educativa y metodologías activas en Educación Secundaria: La perspectiva de los docentes de lenguas castellana y literatura. Revista Fuentes 2016, 18, 65-76. [CrossRef] 
45. Albrecht, J.R.; Karabenick, S.A. Relevance for Learning and Motivation in Education. J. Exp. Educ. 2018, 86, 1-10. [CrossRef]

46. Blanco-Salas, J.; Ruiz-Téllez, T. Propuesta innovadora de valorización de la biodiversidad vegetal del espacio protegido ZIR Sierra Grande de Hornachos. In Proceedings of the 7th Congreso Forestal Español. Sociedad Española de Ciencias Forestales, Plasencia, Cáceres, Spain, 26-30 June 2017.

47. Guío, Y. Naturaleza y Salud en Extremadura: Los Remedios; de Extremadura, A., Ed.; 1a; Assembly of Extremadura: Merida, Spain, 1992.

48. Vázquez, F.M.; Suarez, M.A.; Pérez, A. Medicinal plants used in the Barros Area, Badajoz Province (Spain). J. Ethnopharmacol. 1997, 55, 81-85. [CrossRef]

49. Gregori, P. La Medicina Popular en Extremadura: Análisis Bibliográfico; Universidad de Extremadura: Plasencia, Spain, 2000.

50. Penco, A.D. Medicina Popular Veterinaria en la Comarca de Zafra; Universidad de Extremadura: Plasencia, Spain, 2005.

51. Muriel, M.R. Estudio Técnico de los Recursos no Maderables de la Comarca de Las Hurdes: Las Plantas Medicinales; Universidad de Valladolid: Valladolid, Spain, 2006.

52. Gregori-Cruz, M.P. Medicina Popular en Valencia del Mombuey; Universidad de Extremadura: Plasencia, Spain, 2007.

53. Vallejo, J.R. La etnomedicina en Guadiana del Caudillo (Badajoz); Universidad de Extremadura: Plasencia, Spain, 2008.

54. Vallejo, J.R.; Peral, D.; Gemio, P.; Carrasco, M.C.; Heinrich, M.; Pardo-de-Santayana, M. Atractylis gummifera and Centaurea ornata in the Province of Badajoz (Extremadura, Spain)-Ethnopharmacological importance and toxicological risk. J. Ethnopharmacol. 2009, 126, 366-370. [CrossRef]

55. Pacheco, D.F.P.; Martín Alvarado, M.Á.; Vallejo Villalobos, J.R.; Altimiras Roset, J.; Roura Poch, P. La medicina popular en la ciudad de Badajoz. Revista Estudios Extremeños 2009, 65, 1389-1438.

56. Martín-Alvarado, M.A. Medicina Popular en la Ciudad de Badajoz; Universidad de Extremadura: Plasencia, Spain, 2010.

57. Pérez-Ramírez, I. Conocimiento Local y Uso de las Plantas Aromáticas y Medicinales en Tres Localidades del Sur de Extremadura; Universidad de Sevilla: Sevilla, Spain, 2013.

58. Tejerina, A. Usos y Saberes Sobre las Plantas de Monfragüe. Etnobotánica de la Comarca Natural; Itomonfrag: Cáceres, Spain, 2010.

59. Blanco, E.; Cuadrado, C. Etnobotánica en Extremadura. Estudios de la Calabria y la Siberia Extremeñas; CEP de Alcoba de los Montes, Ed.; CEP de Alcoba de los Montes: Madrid, Spain, 2000.

60. Gutiérrez-García, L.; Labrador-Moreno, J.; Blanco-Salas, J.; Monago-Lozano, F.J.; Ruiz-Téllez, T. Food Identities, Biocultural Knowledge and Gender Differences in the Protected Area "Sierra Grande de Hornachos" (Extremadura, Spain). Int. J. Environ. Res. Public Health 2020, 17, 2283. [CrossRef]

61. Abd-Ei-Khalick, F. Embedding nature of science instruction in preservice elementary science courses: Abandoning scientism, but ... . J. Sci. Teacher Educ. 2001, 12, 215-233. [CrossRef]

62. Kolstø, S.D. Scientific literacy for citizenship: Tools for dealing with the science dimension of controversial socioscientific issues. Sci. Educ. 2001, 85, 291-310. [CrossRef]

(C) 2020 by the authors. Licensee MDPI, Basel, Switzerland. This article is an open access article distributed under the terms and conditions of the Creative Commons Attribution (CC BY) license (http://creativecommons.org/licenses/by/4.0/). 